\title{
Immune Response to other Agents of Calves Persistently Infected with Bovine Virus Diarrhoea Virus (BVDV)
}

\author{
By H. Houe and I. Heron
}

Department of Clinical Studies, Division of Large Animal Medicine, The Royal Veterinary and Agricultural University, Frederiksberg, Denmark and Department of Bacterial Vaccines, State Serum Institute, Copenhagen, Denmark.

\begin{abstract}
Houe, H. and I. Heron: Immune response of calves persistently infected with Bovine Virus Diarrhoea Virus (BVDV) to other agents. Acta vet. scand. 1993, 34, 305-310. The ability of calves persistently infected (PI) with bovine virus diarrhoea virus BVDV to respond immunologically to defined antigens other than BVDV was studied. Five clinically healthy PI calves were studied together with 5 non-PI calves serving as controls. The humoral immune response was tested by measuring the serum antitoxin titre following immunization against tetanus. The cellular immune response was tested by the ability to develop a positive reaction in a cutaneous tuberculin test performed 1 month after immunization against Johne's disease (paratuberculosis). Finally, a skinsensitizing agent, dinitrochlorobenzene (DNCB), was employed to study whether PI calves would react by hypersensitization following skin exposure to DNCB for 7 consecutive days followed by application of DNCB to a new skin area remote from the area that had first been exposed.

The response of PI calves to the various types of antigenic stimuli applied was not significantly different from that of the control calves. Thus, PI calves developed a potent antitoxin response after tetanus immunization, they showed a positive reaction to tuberculin skin test after immunization against paratuberculosis, and were skin sentitized with DNCB.
\end{abstract}

pestivirus; cattle.

\section{Introduction}

Infection with bovine virus diarrhoea virus (BVDV) in pregnant, seronegative cows will almost invariably be associated with intra-uterine infection of the foetus. If infection occurs during the first trimester of gestation, the foetus will develop immunotolerance to BVDV and the calf will become persistently infected (PI) with BVDV for the rest of its life (McClurkin et al. 1984). These PI calves may later succumb to mucosal disease (Brownne et al. 1984) and are, furthermore, important in the transmission of the virus to other animals (Houe 1992; Meyling et al. 1990).

In PI calves, BVDV is located within or in association with cells of the immune system (Bolin et al. 1987; Bielefeldt Ohmann et al. 1987). Accordingly, it might be inferred that the PI animal could have a reduced immune response, not only to BVDV but to other antigenic stimuli as well. The existing evidence is, however, conflicting. Some authors have found that PI animals were able to produce antibodies to infectious agents other than 
BVDV (Steck et al. 1980; McClurkin et al. 1984) and, furthermore, their immune tolerance did not include strains of BVDV other than the one causing the persistent infection during foetal life (Westenbrink et al. 1989). However, it has been found that PI animals had a reduced immune response to bovine leukaemia virus (Roberts et al. 1988), and both healthy PI animals and animals with mucosal disease had a reduced level of $\mathrm{IgG}_{2}$ (Coulibaly et al. 1986; Steck et al. 1980). Also, calves with so-called chronic BVD had reduced numbers of B lymphocytes (Muscoplat et al. 1973) and animals with mucosal disease had an increased T-cell suppressor activity (Larsson et al. 1988). Compared to normal animals, clinically healthy PI calves had reduced numbers of T-cells (Bielefeldt Ohmann et al. 1987), increased T-cell suppressor activity (Larsson 1988), decreased migration of neutrophils and decreased blastogenesis of lymphocytes (Brown et al. 1991). Finally, PI calves had a shorter life span and had an increased incidence of infectious disorders (pneumonia, enteritis and others) than normal calves (Barber et al. 1985; Werdin et al. 1989; Houe 1993).

The experiments reported here were designed to study the humoral and cellular immune response of healthy PI calves following immunization against tetanus and Johne's disease (paratuberculosis), respectively. Also the ability of PI calves to become skin sensitized to dinitrochlorobenzene (DNCB) was studied.

\section{Materials and methods}

Animals

After virological examination of cattle in herds with outbreaks of mucosal disease 5 viraemic but clinically healthy calves were selected. Four calves were Black and White Danish Dairy breed (approximately 1 year old) and 1 was a Jersey calf (approximately $1 \frac{1}{2}$ year old). All 5 viraemic animals were antibody negative. The calves were brought to the Royal Veterinary and Agricultural University. A second blood sample for virus isolation taken more than 3 weeks after the first sample proved that the calves were PI. Five antibody positive and non-viraemic Jersey calves (approximately 6 mo old) served as controls.

\section{Stimulation of the humoral immune system}

All calves were immunized against tetanus (1 $\mathrm{ml}$ Tetapur $\left.{ }^{\circledR}\right)$. Two injections were given 5 weeks apart. Antitoxin titres were determined using an ELISA-technique on serum samples that were taken weekly for 8 weeks following the first immunization (Simonsen et al. 1986).

\section{Stimulation of the cellular immune system}

Immunization against paratuberculosis. All animals were immunized once with 2 $\mathrm{ml} \mathrm{Neoparasec}{ }^{\circledR}$. This immunization was performed 2 days later than the first tetanus immunization. The animals were tested with avian tuberculin prior to and 1 month after immunization. A conventional skin test before the shoulder was used, and skin thickness was measured with a slide gauge before and 48 hours after intracutaneous injection of tuberculin.

DNCB skin sensitization. The procedure described by Brummerstedt et al. (1974) was employed. An $8 \times 8 \mathrm{~cm}$ skin area on each side of the lumbar region was chosen. Hairs were removed with a hair removal agent (depilatory) and the skin thickness measured with a slide gauge. A 2 per cent DNCB solution in absolute alcohol was applied to 1 area for 7 consecutive days. The other area was treated with 2 per cent absolute alcohol only (control area). The DNCB skin exposure was initiated 1 day after the first tetanus immunization. 
TETANUS ANTITOXIN TITER (IU)

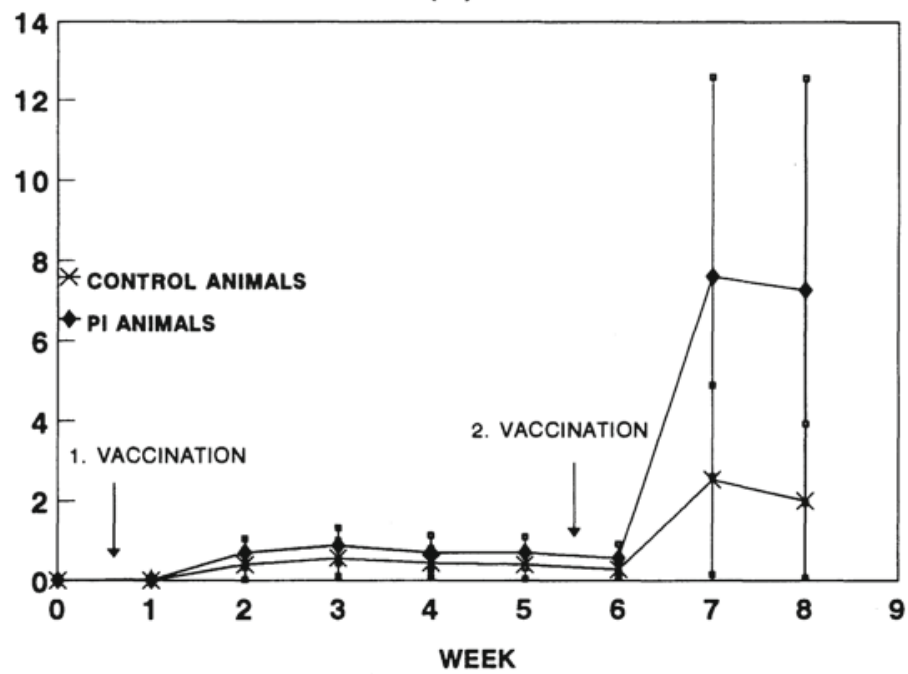

IU: INTERNATIONAL UNITS

Figure 1. Mean tetanus antitoxin titre in 5 PI calves compared to 5 control animals 1 month after immunization with Tetapur ${ }^{\circledR}$.

Two weeks after the last DNCB exposure, hairs were removed on an area on both shoulders and the skin thickness measured. DNCB was applied on one side and absolute alcohol on the other, followed by repeated measurement of skin thickness $24 \mathrm{~h}$ later. The degree of induced hypersensitization was determined as the ratio between skin thickness after and before DNCB exposure.

\section{Blood parameters}

Blood samples were taken once a week. The following parameters were determined: glutaraldehyde gelatination test (indirect determination of immunoglobulin levels), total serum protein, haematocrit, haemoglobin, erythrocyte count and total and differential leucocyte counts, and blood culture for pathogenic bacteria. The glutaraldehyde test was modified for clinical use (Nielsen 1975) from the original test described by Sandholm
(1974). Blood cultivation was performed as described by Houe et al. (In press).

\section{Statistical analysis}

The antibody titres among PI animals compared to non-PI animals against tetanus was determined by two-sample students t-test after logarithmic transformation of the titres. The increase of skin thickness among PI animals compared to non-PI animals after tuberculin test and sensitization against DNCB were tested by two sample students t-test on the ratio between skin thickness after and before stimulation.

\section{Results}

\section{The humoral immune system}

Fig. 1 shows the mean antibody titres to tetanus toxin (In week 7 there was a missing value of 1 PI animal). The PI animals developed higher antibody titre than the controls. In 
Table 1. Tuberculin test of 5 PI calves and 5 control calves 1 month after immunization against paratubrerculosis. Thickness of skin was measured before and $48 \mathrm{~h}$ after injection of avian tuberculin.

\begin{tabular}{rcc}
\hline & \multicolumn{2}{c}{ Skin thickness (mm) } \\
\cline { 2 - 3 } Animal No & Before tuberculin & After tuberculin \\
\hline PI calves: & & \\
1 & 5.5 & 30.0 \\
2 & 6.5 & 12.0 \\
3 & 5.0 & 16.5 \\
4 & 5.0 & 17.5 \\
5 & 5.5 & 20.0 \\
Mean & 5.5 & 19.2 \\
St.Dev. & 0.6 & 6.7 \\
& & \\
Control calves: & & \\
6 & 5.0 & 21.0 \\
7 & 5.5 & 19.5 \\
8 & 4.0 & 16.0 \\
9 & 3.5 & 18.5 \\
10 & 3.5 & 11.0 \\
Mean & 4.3 & 17.2 \\
St.Dev. & 0.9 & 3.91 \\
\hline
\end{tabular}

week 8 the difference was almost significant $(\mathrm{p}=0.07)$.

\section{The cellular immune system}

Immunization against paratuberculosis. All animals were negative at the tuberculin test performed before immunization against paratuberculosis. A negative tuberculin test was defined as less than $2 \mathrm{~mm}$ increase in skin thickness. Table 1 shows skin thickness at the tuberculin test made 1 month after immunization. The mean ratios between skin thickness after and before the tuberculin test were 3.5 for PI animals and 4.0 for controls. This difference was not significant ( $\mathrm{p}=0.49)$.

DNCB skin sensitization. Table 2 shows the skin thickness before and after sensitization with DNCB. The mean ratios between skin thickness after and before sensitization were
Table 2. Skin thickness of $r$ PI calves and 5 control calves before and $24 \mathrm{~h}$ after sensitization with DNCB.

\begin{tabular}{ccc}
\hline & \multicolumn{2}{c}{ Skin thickness (mm) } \\
\cline { 2 - 3 } Animal No & Before DNCB & After DNCB \\
\hline PI calves: & & \\
1 & & \\
2 & 10.0 & 14.0 \\
3 & 6.0 & 15.0 \\
4 & 9.0 & 21.0 \\
5 & 8.0 & 13.0 \\
Mean & 8.2 & 13.0 \\
St.Dev. & 1.5 & 15.2 \\
& & 3.3 \\
Control calves: & & \\
6 & 6.5 & 16.0 \\
7 & 7.0 & 15.0 \\
8 & 5.0 & 21.0 \\
9 & 4.5 & 12.0 \\
10 & 4.5 & 21.0 \\
Mean & 5.5 & 17.0 \\
St.Dev. & 1.2 & 3.9 \\
\hline
\end{tabular}

2.0 for PI animals and 3.2 for controls. This difference was not significant $(\mathrm{p}=0.08)$.

\section{Blood parameters}

Bacteraemia was not detected in any of the animals. There was no difference in any of the measured blood parameters in PI animals compared to controls (data not shown).

\section{Discussion}

Although the immune response against the antigenic preparations used in this study is not necessarily equivalent to the ability to combat infectious diseases, the experiment clarifies if the PI animals are equivalent to non-PI animals in recognizing and reacting to foreign antigens.

The PI animals of the present study showed a 
normal immunological response to all of the 3 antigenic stimuli that they were exposed to. Quantitatively, their humoral and cellular responses were not significantly different from non-PI control calves. This would imply that the PI calves were not tolerant to antigens other than BVDV (i.e. they were immunologically capable of recognizing them as foreign), neither were they immunosuppressed to a significant extent. However, in the DNCB skin sensitization test, although not significant $(\mathrm{p}=$ 0.08 ), the PI calves showed a tendency of a weaker reaction than the controls. Before the exposure the skin thickness among the control calves were smaller than among PI animals, most likely because the controls were younger. Reduced skin sensitization against DNCB among PI animals could have been due to a reduced T-cell mediated immune response. Reduced numbers of T-cells in PI animals have been reported by Bielefeldt $\mathrm{Oh}$ mann (1987) and Done et al. (1980) found that foetal infection with BVDV may be associated with a reduced development of the thymus. It is anticipated that PI calves, although not incapable of mounting an immunological response, may sometimes show certain deficiencies as regards their reactions to pathogens (Howard 1990).

PI animals are often undersized for their age and unthrifty. Furthermore, it is an established practical experience that they have an increased risk of acquiring various infections (e.g. pneumonia and enteritis), and they have higher mortality rates than non-infected calves. This may imply that their resistance to some infections is low compared with non-PI calves. This could either be due to a specific lack of immunological reactivity or it could be a non-specific phenomenon associated with the generally low vitality of the calves. Further studies are needed to examine whether the immunological response of PI calves would vary according to the clinical status of the animals.

\section{Acknowledgements}

This study was made with support from R. Nørtoft Thomsens Foundation, Viktor A. Goldschmidts Fund and Upjohn's Jubilee Foundation.

\section{References}

Barber DML, Nettleton PF, Herring JA: Disease in a dairy herd associated with the introduction and spread of bovine virus diarrhoea virus. Vet. Rec. 1985, 117, 459-464.

Bielefeldt Ohmann H, Rønsholt L, Bloch B: Demonstration of bovine viral diarrhoea virus in peripheral blood mononuclear cells of persistently infected, clinically normal cattle. J. Gen. Virol. 1987, 68, 1971-1982.

Bolin SR, Sacks JM, Crowder, SV: Frequency of association of non cytopathic bovine viral diarrhea virus with mononuclear leukocytes from persistently infected cattle. Amer. J. vet. Res. 1987, 48, 1441-1445.

Brown, GB, Bolin SR, Frank DE, Roth JA: Defective function of leucocytes from cattle persistently infected with bovine viral diarrhea virus, and the influence of recombinant cytokines. Amer. J. vet. Res. 1991, 52, 381-387.

Brownlie J, Clarke MC, Howard CJ: Experimental production of fatal mucosal disease in cattle. Vet. Rec. 1984, 114, 535-536.

Brummerstedt E, Andresen E, Basse A, Flagstad T: Lethal trait A 46 in cattle. Immunological investigations. Nord. Vet.-Med. 1974, 26, 279-293.

Coulibaly COZ, Liess B, Trautwein G, Schleuter G: Quantitative analysis of immunoglobulins $G_{1}$ and $G_{2}$ in blood samples of cattle persistently infected with bovine virus diarrhoea virus. J. vet. Med. B 1986, 33, 685-696.

Done JT, Terlecki S, Richardson C, Harkness JW, Sands JJ, Patterson DSP, Sweasey D, Shaw IG, Winkler CE, Duffel SJ: Bovine virus diarrhoeamucosal disease virus: Pathogenicity for the fetal calf following maternal infection. Vet. Rec. 1980, 106, 473-479.

Houe H: Age distribution of animals persistently infected with bovine virus diarrhoea virus in 22 Danish dairy herds. Can. J. vet. Res. 1992, 56, 194-198.

Houe H: Survivorship of animals persistently in- 
fected with bovine virus diarrhoea virus (BVDV). Prev. Vet. Med. 1993, 15, 275-283.

Houe H, Eriksen L, Jungersen G, Pedersen D, Krogh $H V$ : Sensitivity, specificity and predictive value of blood cultures from cattle clinically suspected of bacterial endocarditis. Vet. Rec. (In press.)

Howard CJ: Immunological responses to bovine virus diarrhoea virus infections. Rev. Sci. Tech. Off. Int. Epiz. 1990, 9, 95-103.

Larsson B: Increased suppressor cell activity in cattle persistently infected with bovine virus diarrhoea virus. J. vet. Med. B 1988, 35, 271-279.

Larsson B, Fossum $C$, Alenius $S$ : A cellular analysis of immunosuppression in cattle with mucosal disease. Res. Vet. Sci. 1988, 44, 71-75.

McClurkin AW, Littledike ET, Cutlip RC, Frank GH, Coria $M F$, Bolin SR: Production of cattle immunotolerant to bovine viral diarrhea virus. Can. J. Comp. Med. 1984, 48, 156-161.

Meyling A, Houe H, Jensen AM: Epidemiology of bovine virus diarrhoea virus. Rev. Sci. Tech. Off. Int. Epiz. 1990, 9, 75-93.

Muscoplat CC, Johnson DW, Teuscher E: Surface immunoglobulin of circulating lymphocytes in chronic bovine diarrhea: Abnormalities in cell populations and cell function. Amer. J. vet. Res. 1973, 34, 1101-1104.

Nielsen $K$ : Glutaraldehydprøven, en metode til påvisning af forhøjet immunglobulinkoncentration i blod. (The glutataldehyde gelatination test. A methot for demonstratation of increased immunoglobulinkoncentration in blood). Dansk Vet.tidsskrift 1975, 4, 652-655.

Roberts DH, Lucas MH, Wibberley G, Westcott D: Response of cattle persistently infected with bovine virus diarrhea virus to bovine leukosis virus. Vet. Rec. 1988, 122, 293-296.

Sandholm M: A preliminary report of a rapid method for the demonstration of abnormal gammaglobulin levels in bovine whole blood. Res. Vet. Sci. 1974, 17, 32-35.

Simonsen $O$, Bentzon $M W$, Heron I: ELISA for the routine determination of antitoxic immunity to tetanus. Journal of Biological Standardization.
1986, 14, 231-239.

Steck F, Lazary S, Fey H, Wandeler A, Huggler C, Oppliger G, Baumberger H, Kaderli R, Martig J: Immune responsiveness in cattle fatally affected by bovine virus diarrhoea-mucosal disease. Zentralbl. Vet.-Med. B 1980, 27, 429-445.

Werdin RE, Ames TR, Goyal SM, De Vries GP: Diagnostic investigation of bovine viral diarrhea infection in a Minnesota dairy herd. J. vet. diagn. Invest. 1989, 1, 57-61.

Westenbrink F, Straver PJ, Kimman TG, de Leeuw $P W$ : Development of a neutralising antibody response to an inoculated cytopathic strain of bovine virus diarrhoea virus. Vet. Rec. 1989, 125, 262-265.

\section{Sammendrag \\ Immunsvaret over for andre agentia hos kalve der er persistent inficerede med bovin virusdiarré virus (BVDV).}

Den immunologiske reaktionsevne hos kalve persistent inficerede (PI) med bovin virusdiarré virus (BVDV) over for andre agentia blev unders $\emptyset$ gt. 5 klinisk sunde PI-kalve og 5 normale kontrolkalve blev unders $\varnothing$ gt. Det humorale immunrespons blev unders $\emptyset$ gt ved at måle tetanusantitoksintiter i serum efter immunisering mod tetanus. Det cellulære immunrespons blev målt ved evnen til at udvise positiv reaktion efter kutan tuberkulintest udført en måned efter immunisering mod paratuberkulose. Endelig undersøgtes evnen til at blive hypersensibiliseret på huden efter applikation af dinitrochlorbenzen (DNCB).

PI-kalvenes immunrespons over for de forskellige antigene stimuli var ikke signifikant forskellige fra kontrolkalvenes immunrespons. PI-kalvene udviklede et højt antitoksintiter efter immunisering mod tetanus, de havde positiv tuberkulintest efter immunisering mod paratuberkulose og deres hud kunne hypersensibiliseres over for DNCB.

(Received March 3, 1993; accepted June 3, 1993).

Reprints may be requested from: H. Houe, Department of Clinical Studies, Division of Large Animal Medicine, Royal Veterinary and Agricultural University, Bülowsvej 13, DK-1870 Frederiksberg C, Denmark. 